\title{
Political Strategy for Using Language Anis Baswedan in the 2017 DKI Jakarta Regional Election Debate
}

\author{
Moh. Aris Prasetiyanto ${ }^{1}$ and Suhardi ${ }^{2}$ \\ ${ }^{1,2}$ Yogyakarta State University, Indonesia \\ ${ }^{1}$ moh.aris2016@student.uny.ac.id, ${ }^{2}$ suhardiuny@yahoo.com
}

\begin{abstract}
This study aims to analyze the use of language Anis Baswedan in the DKI Jakarta Pilkada debate. Data was collected from the DKI Jakarta Election Debate held by KPU and private TV stations. Data were analyzed using the van Dijk model of critical discourse analysis approach. The findings of this study indicate that through the use of language features, Anis Baswedan channeled the influence of power. These linguistic features are, (1) the use of active sentences; (2) the use of my pronouns, us, and us; (3) the use of lexicons of nature and ideology; and (4) Use of metaphors. The ideology contained in the debate text Anies Baswedan is the ideology of the Pancasila. In general, the leadership values contained in the debate text of Anies Baswedan in the DKI Jakarta Regional Head General Election are democratic leadership consisting of several aspects, namely: (1) social justice; (2) national ideals; (3) a balance between rights and obligations; (4) equation; (5) family and national unity; (6) deliberation; and (7) freedom of responsibility.
\end{abstract}

Keyword: Political strategy, Debate, Critical discourse analysis

\section{Introduction}

Today language and power have developed significantly. The realization of these relations in the present era is the use of language that no longer knows space and time. Modern society is increasingly aware of the importance of using language to support someone's independence in establishing relationships. The use of language by people who are skilled at communication can change one's thoughts and attitudes. It shows that the existence and influence of someone in the community environment is influenced by the role of the language he uses when conveying messages, expressing ideas or ideas that are owned. In Fairclough's view, the practice of language shows that language is a practice of power.

Power and language are entities that cannot be separated from politics. In the political sphere, the presence of language is able to operate to present a truth that is manifested in the spread of a system of signs or symbols into the public space. That indirectly brings someone into the scheme of semantic hegemony. Through hegemony, a discourse can determine the community's cognitive structure [1].

Ideology, politics and power have interrelated relationships. Ideology will always be present in the space of politics and power. Because, ideology is a system of thought relating to social and political activities that are disseminated by certain groups or organizations [2].

Ideology or values can be accepted by society through the most complete language unit called discourse. The study of discourse is the whole process of social interaction that becomes

Article history:

Received (January 21, 2020), Review Result (February 24, 2020), Accepted (March 29, 2020) 
text [3]. This indicates that discourse refers to verbal communication in a situational and social context [4].

Critical discourse analysis provides information to the public about the reasons behind the use of language [5]. The language studied in discourse analysis is not merely understood as a study of language but also related to the context. Therefore, when studying a language, it must always look at the social context that is happening. Discourse analysis provides insight into the relationship between language and society, ideology and power [6].

Discourse as social practice is a part of community, product, and social processes that are conditioned [7]. The discourse that develops in society does not arise by itself. Discourse deliberately raised with a specific purpose. Such a phenomenon usually occurs when the election season takes place. The candidate leader candidates are competing to construct his thoughts into a whole discourse to be further conveyed to the voting community.

Political discourse plays an important role in shaping people's thinking and attitudes [4]. The process of producing meaning in political discourse is influenced by powers that have interests. Therefore, political discourse is always interfered with by the game of the power within it. Political discourses include speeches, debates, and political advertisements [8]. Ordinary politicians include certain ideologies when debating. The use of language in debates among politicians is constructive, attacks opponents' arguments, maintains arguments and seeks to convince listeners. One model of language use in the context of political discourse is a debate that was directly conveyed by Anies Baswedan in the 2017 Jakarta regional head election (Pemilukada) campaign.

Anies Baswedan used the debate as a way to gain popular support. During the debate, Anies Baswedan always included leadership values. Anies Baswedan's leadership values can be seen from the language he used when the DKI Jakarta Pilkada debate. Behind the language used by Anies Baswedan there is a representation of leadership values. Disclosure of these values is based on a situational approach. A situational approach is chosen because in the context of the election there is an interaction between leaders and internal situational conditions. The correlation of leadership values with situational approaches during the election cannot be separated from the community's perspective on the role model of a leader.

Leadership values in a situational perspective in this study are based on the Hersey and Blanchard models. referring to the idea of Hersey and Blanchard, Thoha [9] argues that a situational approach is a leadership theory that seeks to find a middle ground between views that say there are universal organizational and management principles, and views that each organization is included in the inner structure of society is unique and has different situations so it must be faced with a certain leadership style. Based on the explanation, the study in this study was limited to the use of Anies Baswedan's language and leadership values in the 2017 DKI Jakarta Pilkada debate.

\section{Critical discourse analysis teun a. van dijk, debate regional general election of DKI Jakarta, and leadership values}

\subsection{Critical discourse analysis teun A. van dijk.}

Discourse analysis that examines how domination of social power, inequality in a text is used to control and influence people's minds [10]. Discourse is also interpreted as a form of interaction and social practice, and analyzing it requires studies from across various disciplines [11]. The main objective of Critical Discourse Analysis is to reveal how power, domination and injustice are practiced, opposed by texts both verbally and in writing [12]. 
The focus of the analysis of van Dijk's model includes 3 aspects, namely (1) text consisting of thematic, schematic, background, detail, intent, coherence, sentence form, pronouns, and lexicon, (2) social cognition, (3) social context consists of the practice of power and access affecting discourse [1]. These three aspects are combined into an analysis unit. In the aspect of the text analyzed is how the structure of the text and the discourse strategy are used to clarify the theme being carried out. In the aspect of social cognition that is studied is how the process of production of text that applies individual cognition. In the aspect of the social context that is analyzed is how the building of discourse that develops in the community towards a problem that is happening [13].

Teun van Dijk divides the text into three levels, namely macro structure, superstructure, and micro structure. Macro structure is the global meaning of a text that can be observed from a topic / theme raised by a text, the superstructure is related to the framework of a text, (such as the introduction, contents, concluding and concluding), microstructure is the local meaning of a text that can observed from the choice of words, sentences and styles [14].

Based on the explanation above, a red thread can be drawn that analysis of the structure of the text is the main step taken to express the ideology and purpose of the production of a text. The text connects textual meaning and comprehensive contextual meaning. Therefore, in this study the use of Anies Baswedan's language in the DKI Jakarta Pilkada debate was analyzed only at the text level to reveal Anies Baswedan's leadership values.

\subsection{Debate}

Debates are related to one form of campaign and propaganda commonly used in general election events. Debate is one of the political discourses commonly used in a country that adheres to a democratic system. In debates, language has an important role in delivering political speech [15]. A person's proficiency in using language in debate shows his dominance and power to others. The success of someone in debating is also able to influence and control the minds of others.

Debate is a political discourse that aims to control the minds of others through language. Referring to van Dijk's view, Aziz and Mohd also mention that mind control can be done through manipulation in the form of persuasion [16]. In line with this opinion, Safro and Krampa argue that the control process takes place through persuasion and manipulation [17]. This means that the most influential groups have more opportunities to control the thoughts and actions of others. The choice of language used by someone in the debate includes the ideologies that are carried out [18]. The ideology contained in the debate discourse is deliberately designed by the discourse to be known by the public. It aims to gain power and perpetuate power.

Debate activities involve the use of language as the main tool for achieving hegemony. The use of language is very effective and elegant if applied to modern democracy like today. Attractive language will make the discourse able to realize power without going through violence.

The debate in the science of modern rhetoric is the art of speaking no monologists who are argumentative. In the monologue, only one person speaks to a group of people. Debate is a communication practice that intensely spurs a speaker to build an argument. The argument that was built in the debate was limited to a relatively short time. In debating activities, the speaker is limited by a moderator whose function is to interrupt a debate and regulate the course of the debate so that it can run well and perfectly. Debate is a conflict of argument. Each issue must have various perspectives on how to respond to and respond to the issue, which contains the 
reasons why someone can support or not support an issue that arises. The purpose of the debate is to explore ideas and reasons behind the point of view.

This study will analyze the debate of Anies Baswedan in the 2017 DKI Election Debate held by the DKI Jakarta KPU. The debate in the event was not only manifested in the form of conveying ideas but also trying to influence listeners or viewers so that they would follow what was conveyed by the candidates for the Governor of DKI Jakarta.

\subsection{Regional general election of DKI jakarta 2017}

Pemilukada or regional head elections become a supporting tool in realizing a democratic constitutional system. Democracy is an important aspect related to government with a power hierarchy consisting of a national political system that contains regional political subsystems at both the provincial and district and city levels. With regard to regional politics, local democracy is built to provide the portion gained by the local community in giving legitimacy to the executive elite. Citizens who live in democracies have the opportunity to take part in the decision-making process, that is, it is a representation of a central mechanism for forming political forces [19]. Therefore, the five-year event is a place for people in each area to use.

One of the post-conflict local election at the provincial level which attracted the attention of many parties to become a national topic was the election of regional heads of DKI Jakarta. Although in 2017 the implementation of regional head elections was held simultaneously in seven provinces, 76 districts, and 18 cities or a total of 101 regions, public enthusiasm remained concentrated in the grand election of the governor and deputy governor of DKI Jakarta. This is very reasonable if public concentration is so great for the Jakarta governor election, because Jakarta is the center of political authority. Jakarta as the capital city of the nation is described as central of power and politics.

The people as the highest holders of sovereignty have an interest in choosing their leaders who are considered capable of leading Jakarta for five years. Therefore, the people must recognize the track record, vision and mission of the candidates for governor and deputy governor of DKI Jakarta. As an effort to introduce candidates for governors and deputy governors, the Regional Election Commission as the organizer of regional elections provides stages in the form of candidates' campaigns and debates. Campaigns and debates can be a tool for prospective governors to gain people's sympathy.

\subsection{Leadership values}

The value in the KBBI dictionary is the characteristics (things) that are important or useful for humanity. These characteristics or important things are based on a belief. Value according to Nurul Zuriah is a pattern of beliefs about good things to do and bad things that must be avoided in behaving [20]. From this understanding value can also be interpreted as something that is attached to the object so that it is liked and sought by many people. An object will be valuable if there is a subject who gives an assessment of the object. Good and bad judgments given to an object, depending on the rules that apply in the community and the experience of the person giving the assessment. Society or individuals must recognize, choose, and determine what values are used as guidelines in behaving and becoming habits in social life. Values are found in various aspects of life. One of them is found in aspects of leadership.

Leadership has a broad understanding. According to Day [20] interpreting leadership as a process carried out in various ways to influence others to achieve common goals. This is in accordance with the opinion of McCleskey [21] which states that leadership is a process of 
influencing thoughts, feelings, behavior, and directing all existing facilities to achieve the goals set together.

Based on the explanation above, it can be concluded that the value of leadership is an attitude in the form of belief, the principle of life in behaving from a leader to an audience. Thus, each leader is ensured to have leadership values that are used to manage the organization, the period or the community within his domain.

\subsection{The data acquisition setup}

The data and results obtained from this study are verbal data in the form of descriptions of the use of language Anis Baswedan. The subject of this research is the debate text Anis Baswedan taken from the debate held by the DKI Jakarta KPU 2017 and the debate held by private TV stations. The debate held by the KPU consisted of four debates, namely the first debate on January 9, 2017; second debate on January 20, 2017; third debate on 10 February 2017; fourth debate on 12 April 2017; the fifth debate was the debate held by private TV on December 10, 2016. The object of this study was the language feature used by Anis Baswedan in the 2017 DKI Jakarta Pilkada debate. Data collection in this study was conducted by observation of text and literature. The data that has been collected is then analyzed using discourse analysis developed by van Dijk as a determining element.

\section{The dataset}

\subsection{Sentence form}

The sentence forms contained in the language used by Anies Baswedan are in the form of active sentences. The following are presented active sentence data.

Table 1. active language sentences

\begin{tabular}{|c|c|}
\hline DATA & KODE \\
\hline Kami hadir berdua untuk memastik an kesejahteraan dan keadilan hadir bagi seluruh warga Jakarta. & KA01 \\
\hline Kami akan tegas memerangi narkoba hingga tuntas di kota ini & KA03 \\
\hline Kami undang stake holder untuk terlibat & KA22 \\
\hline Kita akan tegas menghadapi mereka (Alexis). & KA27 \\
\hline Kita harus rawat kebhinekaannya & KA44 \\
\hline KA55 \\
\hline Kita akan naikkan tiga atau emapat kali lipat gaji paud untuk guru-guru di jakarta & KA73 \\
\hline Kami berikan KJP Plus untuk anak-anak yang putus sekolah & KA179 \\
\hline
\end{tabular}

Sentences that have the same pattern as the active sentence delivered by Anies Baswedan are not just the truth of sentence structure or grammar. Grammar through the use of sentence forms is a text-making strategy to display certain meanings or meanings. More in van Dijk in the theory of discourse analysis explains that patterns in the arrangement of a sentence determine meaning. The sentence used by Anies Baswedan as in the table above has the same pattern. The subject pattern acts as (things that explain) and the predicate as (things explained).

Our pronouns in the table occupy the function of the subject. Our subject in this sentence is a pronoun that refers to two people, namely Anies Baswedan as a candidate for governor and Sansiaga Uno as a candidate for deputy governor. "Sentence We are here both to ensure prosperity and justice are present for all citizens of Jakarta." The subject is that we are second in attendance (Anies and Sandi), to ensure a predicate, while the object is welfare and justice present for all Jakarta residents. The sentence pattern confirms that the leadership of the 
governor and deputy governor of DKI Jakarta under Anies Baswedan and Anies Sandi has an optimistic attitude capable of working for citizens to advance Jakarta. The sentence "We provide KJP Plus for children who drop out of school." We (Anies and Password) are domiciled as subjects, giving domicile, KJP Plus for children who drop out of school as an object represents Anies Baswedan as a leader who cares about poor people who do not get access to education. Through these sentences Anies also wants to emphasize that he is committed to educating the nation's life through giving access to education. Sentence "We will firmly fight drugs until they are finished in this city." We (Anies and Sandi) occupy the subject, the title is filled with strict fighting, drugs to the point of being an object, in this city as a place to show the meaning of the governor and deputy governor's leadership DKI Jakarta under Anies Baswedan and Anies Sandi are committed to enforcing the applicable rules, namely for drug dealers to be subjected to legal action with the intention that the perpetrators deter and citizens of Jakarta are protected from drug problems.

The KA27 sentence is a form of prominence of Anies Baswedan's attitude as a prospective leader who upholds the value of equality. That is, every person in DKI Jakarta has the same position in the eyes of the law. If someone is involved in a legal case, it will be processed expressly based on the mechanism of Annies or the applicable legal rules. The sentence form KA73 and KA44 is the way Anies Baswedan shows the public that he is a leader who prioritizes deliberation in making decisions and prioritizing unity even though people have different views. The KA55 sentence emphasizes Anies's partiality towards honorary educators. This indicates that Anies is also a leader who focuses on the issue of inequality in Jakarta.

The form of the sentences as described above is generally about ideology and the attitude that is displayed by Anies Baswedan as a candidate for the Governor of DKI Jakarta. The use of Anies Baswedan's active sentence in the debate is a strategy of self-prominence as a subject occupying a central position. This has an impact on the prominence of the attitudes and ideologies carried out by Anies Baswedan during the debate more easily understood by the public or listeners.

\subsection{Lexicon}

The lexicon in the language used by Anis Baswedan in the DKI Jakarta Pilkada reflects the nature and ideology.

Table 2. Lexicon data

\begin{tabular}{|c|c|c|}
\hline LEKSIKON & DATA & KODE \\
\hline Musyawarah & Tetapi kami akan musyawarah. & LK30 \\
\hline Berdialog & $\begin{array}{c}\text { Jakarta bukan kota pertama kali code di yogya ada contohnya, di malang ada } \\
\text { contohnya, di mana warga diajak berdialog, warga diajak berdiskusi, dilakukan } \\
\text { peremajaan secara bertahap }\end{array}$ & LK32 \\
\hline \multirow{2}{*}{ Ijinkan } & $\begin{array}{c}\text { Untuk Pak Basuki dan masyarakat Tionghoa Indonesia, ijinkan di malam Imlek } \\
\text { ini ijinkan kami mengucapkan gong xi fachai }\end{array}$ & LK50 \\
\cline { 2 - 4 } & $\begin{array}{c}\text { Ijinkan warga Jakarta merasakan aset 100 jutanya dalam bentuk dwon payment } \\
\text { nol rupiah, terimaksih. }\end{array}$ & LK53 \\
\hline Pendidikan & Berikutnya akses pada pendidikan berkualitas dan tuntas & LK57 \\
\hline Memastikan & $\begin{array}{c}\text { Dan ijinkan kami memastikan bahwa ketika kami diamanati maka semua } \\
\text { warga Jakarta akan bekerja bersama untuk mewujudkan kota yang maju warga } \\
\text { yang bahagia, bukan sebagian semuanya, itu komitmen kami. }\end{array}$ & LK55 \\
\cline { 2 - 3 } & $\begin{array}{c}\text { Konsentrasinya pada memastikan warga sehat, lingkungan sehat dan memiliki } \\
\text { personalia yang hadir di tempat itu }\end{array}$ & LK16 \\
\cline { 2 - 3 } & \multicolumn{2}{|c|}{}
\end{tabular}




\begin{tabular}{|c|c|c|}
\hline Tegas & $\begin{array}{l}\text { Kami akan tegas. Kami tidak akan melakukan tindakan-tindakan yang } \\
\text { bertentangan dengan keadilan }\end{array}$ & LK37 \\
\hline Memerangi & Kami akan tegas memerangi narkoba hingga tuntas di kota ini(transkip kesatu) & LK22 \\
\hline Hadirkan & $\begin{array}{c}\text { Dan di sini akan kami hadirkan } 44 \text { pusat pertumbuhan ekonomi di Jakarta yang } \\
\text { akan menumbuhkan lapangan pekerjaan. (transkip kesatu) }\end{array}$ & LK25 \\
\hline Berpihak & $\begin{array}{l}\text { Karena itu, kami akan berpihak kepada perempuan, kami akan berpihak kepada } \\
\text { kaum difabel, dan kami kan tegaskan keberpihakan kita (ketiga) }\end{array}$ & LK47 \\
\hline
\end{tabular}

The words "deliberation" and "dialogue" were chosen by Anies Baswedan to show the nature of the public that he was a leader who put forward dialogue. He uses dialogue and deliberation to take policies and solve problems. Policy making through deliberation and dialogue indicates that Anies Baswedan is a leader who is capable and willing to absorb the aspirations of citizens and leaders who allow their people to criticize their policies. This shows that he is an open leader. Open to criticism, input or suggestions. These two words are also used by Anies in an effort to solve the problem. The phenomenon of public protest is caused by a deadlock or there has been an imbalance between the people's will and government policy. Responding to this issue, dialogue and deliberation were put forward by Anies Baswedan as a way to resolve community problems, especially those related to public spatial planning.

Throughout the ongoing debate, Anies Baswedan used diction "deliberation" with the aim of building the assumption of the community or listeners that he was truly a democratic leader. Starting from Anies' idea to create a government system that is "good governance" and "open governance", then diction "deliberation" and diction "dialogue" are the right choices to concretize ideas from abstract into more detail. The words "deliberation" and "dialogue" can correlate with the meaning of involving many parties. When someone talks or has a dialogue, there is an open internal communication. One another can criticize, bring up ideas to clash ideas. So that the results of deliberation and dialogue are a filter of the best ideas after the process of exchanging ideas openly, logically, objectively, and transparently. Thus the assumption that Anies Baswedan wants to build that he is a democratic leader is a leader who can be accepted by most people in Jakarta who have heterogeneous characteristics and character.

The word "allow" used by Anies Baswedan is Anies Baswedan's political strategy to portray himself as a polite leader. This strategy was used by Anies Baswedan to show a different impression from his political opponents. Modesty is an inherent characteristic of the Betawi people who are indigenous people and majority tribes who live in Jakarta. So that the use of the word is quite familiar among the people of Jakarta. The use of "diction" can also be interpreted as Anies Baswedan's diplomatic strategy in the success of the work program (DP 0\%).

"Allow" jurisdiction also shows the impression of being close to other people. As a prospective leader, he places himself by sitting down with others. The word allowed Anies to be used eight times during the debate. This indicates that courtesy is inherent in him

The lexicon "education" was used by Anies Baswedan 17 times during the debate. The "education" lexicon with this number signifies Anies Baswedan's commitment to change Jakarta. Education is a fundamental key to the welfare of the citizens of Jakarta. Efforts to improve the quality of education are a form of Anies Baswedan's commitment to improving the quality and quality of teachers. As a candidate for governor, Anies always emphasizes the importance of building human resources rather than physical development. Development or improvement of these resources can be done effectively through the creation of quality education. In the next diction, Anies added complete words. That means, there is an emphasis, there is a commitment from Anies Baswedan that quality education is the main platform, a driving factor to educate the nation's life in general and advance social and economic development in the DKI Jakarta area. 
Through the "ensure" lexicon in the first debate, Anies intends to introduce the ideology of leadership to the people of Jakarta that under his leadership Anies is a leader who truly works for his people. The work in question is ensuring that the welfare and justice can be felt by the citizens of DKI Jakarta without exception. Through the "ensuring" lexicon also shows ideology Anies Baswedan as a fair leader who is present for the citizens of Jakarta. Fair is defined as a democratic leader. Democratic leaders can be seen from the attitude of Anies Baswedan who does not discriminate between social, ethnic and religious status). His work and wisdom are dedicated to all heterogeneous people.

The use of strict words has several purposes. In the sentence "We will be firm, we will not take actions that are contrary to justice" Anies Baswedan wants to show the ideology that he is a clean leader, never involved in legal cases. With these tools Anies wants to show courage to lawbreakers not to play with him.

The "fight" lexicon in the data is a representation of the power possessed. The word fighting is included in the category of transitive sentences that require objects. The impression that Anies Baswedan wants to teach through the use of the word is through the power he has, there is a high commitment to crack down on drug problems in Jakarta. The word "fighting" is used by Anies Baswedan to get in touch with actors who disobey the rules or break the law. The word "fighting" is used by Anies to show a firm attitude to drug dealers and corruptors.

The word "present and present" is a form of representation of Anies Baswedan's power. Under the authority owned, Anies is committed to advancing Jakarta by resolving unresolved problems. The strategy of political discourse with the use of the word aims to provide hope to the public about the attitude Anies intends to take in bringing change in Jakarta. The use of the word "present" in the sentence is a form of sincerity of efforts to alleviate unemployment, and poverty in Jakarta. Anies prepared two solutions at once. That is, on the one hand he prepared the readiness of human resources by making access to quality education, on the other hand Anies also prepared land or a place for self-realization in the form of presenting 44 centers of economic growth.

The word "siding" in the sentence is an ideological representation of Anies Baswedan as a leader who strives for gender equality and justice. The use of the word is a form of fairness Anies Baswedan in leading Jakarta which has various social statuses. Anies' attention also shows Anies's partiality towards women and also those who experience mental and physical retardation.

Based on the findings of the lexicon it can be concluded that the ideology of Anies Baswedan belongs to the category of Pancasilic ideology. This can be seen from the use of lexicons that reflect the values of the Pancasila and are raised continuously from the debating text delivered by Anies Baswedan. Anies Baswedan maintained his ideology by making programs for the progress of DKI Jakarta.

\subsection{Pronouns}

Table 3. Pronouns (saya)

\begin{tabular}{|c|c|}
\hline DATA & KODE \\
\hline Dan saya melihat, ke depan, pengelolaan perencanaan harus melibatkan warga. \\
Pemilik kota ini adalah warga. & KG11 \\
\hline $\begin{array}{c}\text { Dan saya beri catatan, perda yang disusun tidak harus perda yang dikaitkan dengan } \\
\text { pidana, penutupan, pelarangan2 bisa menggunakan perda, tak selalu perda harus } \\
\text { kaitannya dengan pidana ketika terkait dengan persoaln narkoba }\end{array}$ & KG13 \\
\hline $\begin{array}{c}\text { Karena itu saya akan konsentrasi pada peningkatan mutu guru dan mutu pelatih } \\
\text { dalam semua sektor pelatihan karena di sini kuncinya. }\end{array}$ & KG34 \\
\hline
\end{tabular}


The use of my pronouns in the sentence "And I see, going forward, planning management must involve citizens. The owner of this city is a citizen "is a form of self-proclaimed Anies Baswedan as a democratic leader. The authority he has in taking a policy seeks to involve citizens. This involvement takes the form of deliberations between the regional government and the community. The KG13 sentence is a form of self-expression of Anies Baswedan as a candidate for the Governor of DKI Jakarta who has the authority to make regional regulations. This indicates that Anies Baswedan is capable of carrying out his duties as a leader. The KG34 sentence is an expression of Anies Baswedan's self-reliance regarding Anies' commitment to the intellectual life of the nation. Anies Baswedan's prominence in the KG35 sentence is as a democratic leader who emphasizes family and unity. The use of the pronoun "I" is most widely used by Anies Baswedan in expressing the vision of education. There are three times the use of these pronouns during the debate continues. In general, the use of pronouns "I" in the debates held by DKI Jakarta KPU and Net TV stations as a whole contained self-prominence and forms of responsibility or social roles that Anies Baswedan had as a candidate for DKI Jakarta leaders. The use of the pronoun "I" is a strategy used by Anies to introduce herself to the wider community that she is a leader who has appropriate positive attitudes to be chosen as the Governor of DKI Jakarta for the period 2017-2021.

Table 4. Pronouns (kami)

\begin{tabular}{|c|c|}
\hline DATA & KODE \\
\hline $\begin{array}{c}\text { Kami tidak akan melakukan tindakan-tindakan yang bertentangan dengan keadilan. Tetapi kami } \\
\text { akan musyawarah }\end{array}$ & KG46A \\
\hline $\begin{array}{c}\text { Karena kami mendedah pendidikan lebih dari sekedar soal persekolahan. } \\
\text { Salah satu masalah transportasi di Jakarta adalah karena para pengemudi tak pernah mengalami } \\
\text { proses pendidikan peningkatan mutu profesi. Kami akan melihat pendidikan lebih luas dari } \\
\text { sekolah-sekolah, makasih }\end{array}$ & KG48A \\
\hline Kami tidak punya kaitan dengan persoalan masalalu di kota ini. & KG49A \\
\hline $\begin{array}{c}\text { Justru kebaruan yang kami tawarkan adalah kebaruan yg sanggup berhadapan dengan siapa } \\
\text { saja, tanpa kompromi dengan keyakinan transparansi kebenaran dipihak kami }\end{array}$ & KG50A \\
\hline $\begin{array}{c}\text { Kami justru bagian dari yang ingin memastikan di Jakarta Anda melanggar Anda di hukum } \\
\text { KG51A }\end{array}$ & KGata \\
\hline
\end{tabular}

From the table, the use of the personal pronoun "kami" used by Anies Baswedan as a whole refers to two parties, namely Anies Baswedan and pair number 3 (Anies Baswedan and Sandiaga Uno). The "us" pronoun is used Anies Baswedan aims to convey goals or campaign promises, warnings, and congratulations. Anies Baswedan uses our pronouns more to express collaborative and drug governance systems. Each 4 times. The total use of the pronoun "us" during the debate is 24 times. Overall the pronoun "we" functions to distinguish social functions. That is, differentiating between Anies' obligations as a candidate for governor, and the obligations and rights of the people of Jakarta as a people under the leadership of Jakarta Governor candidate Anies Baswedan. The use of these pronouns also refers to the group Anies Baswedan who has differences with other groups (political opponents). The group that is on 
the side of Anies has specificity that is demonstrated through the use of our pronouns in the debate. so that speciality raises its own identity that distinguishes it from other groups.

Table 5. Pronouns (Kita)

\begin{tabular}{|l|c|}
\hline \multicolumn{1}{|c|}{ DATA } & KODE \\
\hline $\begin{array}{l}\text { Lalu kita didik anak-anak itu, sehingga mereka menjadi anak-anak yang berakhlak, } \\
\text { anak berkarakter, kompeten }\end{array}$ & G97 \\
\hline $\begin{array}{l}\text { Yang tidak kalah penting dari itu sosial ekonomi kita, semua ikhtiar ini menjadi tak } \\
\text { bermakna ketika narkoba hadir }\end{array}$ & KG98 \\
\hline $\begin{array}{l}\text { Tidak sedikitpun ada toleransi karena seluruh ikhtiar kita menjadi tak bermakna begitu } \\
\text { hadir narkoba }\end{array}$ & KG99 \\
\hline $\begin{array}{l}\text { Karena itu justru yang menjadi penting bagian kita adalah kita tidak mendekati } \\
\text { masalah kemisikinan semata-mata sebagai masalah sosial, tapi masalah peningkatan } \\
\text { kesejahteraan }\end{array}$ & KG100 \\
\hline \begin{tabular}{l} 
Kita gerakkan sektor swasta, bekerja bukan yang besar-besar saja \\
\hline
\end{tabular}
\end{tabular}

Our pronouns used by Anies in the debate have the function of reinforcing ideas or ideas that seem to be made jointly with the parties concerned. This function can be seen from the process of engaging listeners into the social reality that Anies Baswedan wants to express. The use of our pronouns is the highest number among other pronouns used by Anies in the debate. The number of uses is 64 times. Of these there are 21 times the use of "we" pronouns which aim to reveal the issue of education. This indicates that Anies Baswedan is a prospective leader who has the character of collaborative leadership that highlights the issue of education. Education is the main factor to improve the welfare of the people of DKI Jakarta.

\subsection{Metaphor}

Based on the results of the analysis that has been carried out on the debate text of Anies Baswedan when the 2017 DKI Jakarta Pilkada debate held by the KPU and the private sector there is the use of metaphors related to power, politics and ideology as follows.

"All these efforts become meaningless when drugs are present" (MTF01A)

"We will firmly fight drugs until they are finished in this city" (MTF02A)

The metaphor in the sentence (MTF02A) has an affective element of the function of the language regarding who has the authority or the right to say something in the public domain. This is closely related to social status and power. Related to this, Anies Baswedan positioned himself as a candidate for governor who would make policies to build a social and economic system and try to protect its citizens from the dangers of drugs that could disrupt the continuity of the development. The metaphor in the sentence is characterized by the use of the word drug present and fighting drugs. The figure of speech "present" was uttered by Anies with a full emotional expression indicating that the presence of drugs in the capital had a negative impact on the socio-economic development of the people of Jakarta. The figure of "fighting" has a strong message that Anies Baswedan is a candidate for the Governor of DKI Jakarta who will be at the forefront as a leader who cares about the continuity of socio-economic development. 
The development will succeed when Anies succeeds in cracking down on drug distributors and providing an immune system to its citizens in the community.

"If we heard earlier, the first candidate pair had given the fish, the second candidate pair gave the hook, and the hook was given but if the pool was still there" (MTF03A)

"Our part is ready, making sure the pool is still available" (MTF04A)

The use of diction "fish, hook, and pond" is a metaphor used by Anies Baswedan in relation to the functions of power and ideology. Indirectly, the use of the metaphor is used by Anies Baswedan to insinuate debating opponents or political opponents. Contextually meaning, Jakarta is a state capital that has poor citizens who are of concern. The resolution of the poverty problem that Anies Baswedan strives for is not solely using the social problem approach but how the local government is able to improve the welfare of DKI citizens. So he offered the idea of "preparing", "ensuring the pool". The pool metaphor implies the meaning of employment. Anies deliberately compared the pool metaphor with fish and hook. This was done to influence and bring the community to participate in choosing the solutions presented by the candidates for the Governor of DKI Jakarta. According to Anies Baswedan, jobs that are metaphorically in the "pool" diction are something that is really needed by the people of Jakarta. The concrete form of Anies' idea is that he will present 44 centers of economic growth in Jakarta that will foster employment. Thus, the idea suggested that the solution presented by Anies was the answer to improve people's welfare. The metaphor is also supported by other texts that are spoken literally, so that the community is able to understand what Anies Baswedan meant.

"His vision is to talk about the stomach and the wallet, there are no morals, there are no characters" (MTF07B)

The metaphor contains Anies satire that building education is not just education to prepare graduates who are ready to work, oriented towards the acquisition of material (stomach, brain, and wallet). According to Anies, what is needed for the people of Indonesia (especially the people of DKI Jakarta) is education that fosters moral character and performance character. Moral character means honest, sincere character, complete, faithful. Performance character; hard work and complete work.

"If we imagine that Jakartans are like bodies, then the transportation route is that blood vessels can flow to all parts of the transportation system" (MTF09)

"Making the lrt and brt as the backbone' (MTF10)

"The veins" are interpreted as transportation routes that can connect people who want to travel from one place to another easily and effectively. Therefore, Anies made the policy of mass public transportation systems integrated with routes that were updated or structured. Integrated mass public transportation positions the "MRT, LRT and BRT lines as the backbone". The backbone in question is the main route that will become a priority in resolving congestion problems in Jakarta. The two metaphors used by Anies serve to clarify the ideas raised to the public so that people are easy to understand.

"Jakarta residents now never feel like they are on the coast, it's just called Sundanese, where the wives are waving, nothing"

The expression is a form of Anies Baswedan's attitude towards reclamation policy. Jakarta has a charming array of beaches, but it seems to be different when there is reclamation. The people of Jakarta are hindered by reclamation, so they cannot enjoy the beauty of the waving coconut trees or leaves from waving coconut trees. "Nyiur waving" symbolizes the beauty of the Jakarta beach with the shade of coconut trees that residents should have felt.

"So they are pursued with targets, not pursued by fear" (MTF12) 
The word "pursued" is a form of commitment that has been agreed between the governor and his staff in carrying out the work program. The expression also correlates with how a leader is able to organize the elements in his authority to create good governance and open governance.

"This leader must embrace not hit" (MTF08)

The word embracing this expression means that leaders must encourage the motivation of staff or government officials under their leadership. Leaders are not a cause that can reduce motivation.

"We will turn it all into a child-friendly city, disabled-friendly, female-friendly and not very drug-friendly, that's what we will do" (MTF13)

Friendly words are a form of Anies policy in seeking justice for children with disabilities, women, and taking firm action against drug cases. Anies' commitment is a representation of the sincerity of leaders in realizing justice for every citizen regardless of gender, age, and social status.

"While what we have to do is institutionalize the solution" (MTF14)

Institutionalizing solutions is Anies step in creating a child-friendly social atmosphere. The metaphor of institutionalizing the solution means that every problem of violence in the school controls it in the school level group and cluster at the city level. Problem solving through deliberative mechanisms under the authority of the local government.

"Insyaallah, there will be a solution to congestion" (MTF15)

The bottlenecks in question are common things that occur between the executive and legislative institutions in the level of the regional government in preparing the APBD. The solution to avoiding congestion according to Anies is that the APBD must be guided by the RPJMD, the aspirations of the people, the process of preparing it transparently, and communication and mutual respect.

"And we do this element, so we will make education in Jakarta an socio-economic escalator, because he raises the class of people upwards" (MTF20)

The word escalator is a form of acceleration, an effective tool, feels light in an effort to bring change to improve social and economic well-being.

"The solution is why we make a housing program with a zero rupiah DP?" (MTF21)

DP zero rupiah is Anies' idea in overcoming the problem of home ownership for the poor. The zero rupiah DP is defined as the cost of "Dwon Payment" for free or without DP. The community as the consuming text is asked to imagine the concept of zero rupiah DP which can be said as a new idea. The use of the method gives a mental picture that is easily understood by the community.

\subsection{Leadership values}

The value of Anies Baswedan's democratic leadership can be seen from verbal expressions in linguistic communication in the DKI Jakarta Pilkada debate. The forms of democratic leadership values in detail are presented below.

\subsubsection{Social justice}

During the debate, Anies Baswedan included the values of social justice in verbal expressions. The total value of justice is 107 times. This is the most dominant value found in Anies Baswedan's verbal expression. The value of social justice is contained in the following data.

"The solution is why we make a housing program with a zero-rupiah DP" 
The data is a form of representation of democratic leadership. The democratic aspect lies in Anies Baswedan's concern for $41 \%$ of Jakarta residents who do not have a home. Residents who do not have a home are residents who have the ability of a lower-class economy. Data of $41 \%$ for residents of the capital city is not a small amount, moreover the problem has occurred for a long time and has not been resolved significantly.

The data can be interpreted two things. First, the use of our pronouns is an way for Anies Baswedan to invite many parties to get involved. Indirectly the solution presented by Anies Baswedan is a solution that seems to get the approval of all those present in the debate forum. Second, the sentence contains the legitimacy aspects of power. The zero-rupiah DP policy is a product of the power that Anies Baswedan had when he was elected governor.

The plan for the zero-rupiah DP program is considered to provide convenience for the poor in Jakarta. This facility indicates that Anies Baswedan is fair to disadvantaged families.

\subsubsection{National ideas}

One of the criteria for democratic leadership is the fulfillment of policies that support efforts to educate the nation's life. Verbal evidence included in the category is in the form of a sentence "Next access to quality and complete education". Access to quality education has a significant influence on economic, social, cultural and political aspects. Therefore, Anies Baswedan paid more attention to his policies on education. "Quality Education" is the goal of education, diction "complete" refers to efforts to implement programs in the field. The purpose of Anies Baswedan's version of quality education is education that is oriented not only to the acquisition of material, but also to improve the quality of faith and piety and foster work character and moral character.

\subsubsection{Balance between right and obligations}

The balance between the rights and obligations of a statement in the form of a commitment to carry out duties as a leader for all groups. Anies Baswedan's commitment to carrying out his duties and obligations as a leader is reflected in the following quotations.

The sentence informs Jakarta residents that the intention of Anies Baswedan's wishes and his partner to run for governor and deputy governor is to bring Jakarta to be prosperous and just. These two things are commitments that Anies Baswedan wants to realize to the people of DKI. The word ensure that contained in the quote indicates the power hegemony used by the leader in guarding his program from discourse to materialization. The phrase for all citizens of Jakarta is a form of orientation or policy direction that is aimed at all citizens without exception. This indicates that Anies Baswedan's policy was allegedly felt by and for the people.

\subsubsection{Responsible freedom}

The value of responsible freedom contained in Anies Baswedan's debating text includes freedom of association and freedom of thought or opinion. The value of freedom of association amounts to 1 time verbal expressions and the value of freedom of opinion amounts to 25 .

"You have a different mind, we have a dialogue, but if you force your mind, you are dealing with the law and we are zero compromising anyone who violates the law anywhere, anytime"

\subsubsection{Equations}


The value of equality is a leadership value that shows a leader views each individual as having the same rights and obligations in the eyes of the law. Anies Basewedan entered this score 16 times during the debate. This value also contains a policy that does not favor one group.

"We will firmly face them (Hotel Alexis)"

The quote is a form of assertiveness of Anies Baswedan's attitude as a prospective leader who gives equal treatment in the eyes of the law. The same treatment in the eyes of the law is one of the criteria for democratic leadership. The sentence also provides information to Jakarta residents that everyone who lives in Jakarta is under the rules of the DKI Jakarta Government. Every citizen has the right to do something but still has to comply with applicable regulations.

\subsubsection{Family and national unity}

The value of kinship and national unity is the universal value adopted and believed by the Indonesian people, including the citizens of Jakarta. The values in question include upholding tolerance, fostering and developing a shared life in togetherness through cooperation that respects and respects the strengths and weaknesses of each individual, and promotes mutual cooperation. The value of the equation in Anies Baswedan's verbal expressions is 13 times. "For Pak Basuki and the Indonesian Chinese community, allow this night to allow us to say gong xi fachai"

The text quote is a representation of the value of tolerance. The sentence was uttered by Anies Baswedan as a form of expression of appreciation to Basuki Cahaya Purnama who was of different ethnicity, beliefs, and political opponents. This gentle attitude is a reflection of a leader who wants kinship and unity.

"Yes, I want to underline that Indonesia is built for all groups not for one or two groups. And remember the founder of this republic never mentioned the term minority never, never, never mentioned the majority, why? Because the majority minority is a matter of size. If the group is about diversity"

"We must take care of its diversity"

Contained the meaning of unity values. The sentence uttered by Anies Baswedan can be interpreted as a form of affirmation that he is a leader who upholds persatun. Jakarta is a miniature capital city inhabited by a variety of tribes, ethnicities, cultures, and religions at the center of public attention both regionally and nationally. The differences are interpreted as a force that can make Jakarta a city, a more developed region without disputes. The text is a comparison between the choice of the words "group" and "diversity" with "minority" and "majority". The word "gologan" gets more emphasis to provide understanding to the community that the Jakarta community does consist of various groups, the problem is not a lot or at least followers of a group, but that group difference is actually unity (diversity). If there is only one arbitrary group, the term diversity becomes irrelevant. Because of that, in the quote from the text KA30 Anies Baswedan, he again took care of him. The word "care" in the sentence includes the active verb. The word has the same meaning with (1) always maintained, (2) guarded, (3) taken care of. The meaning of the word if ignored, there will be problems that have the potential to collapse unity.

\subsubsection{Discussion}

The value of deliberation is a statement in the form of decision making based on deliberation. During the debate Anies Baswedan entered the score 9 times.

"But we will have a discussion" 
Deliberation in the sentence is pronounced clearly and firmly. This indicates that Anies Baswedan is a leader who upholds democratic values. The deliberation step is taken to take a balanced and best-judged decision. Therefore, the decision taken cannot be taken unilaterally. There is a mechanism for deliberation taken.

One of the pillars of democracy is the involvement of the people. The people can be involved through a forum consultation mechanism, deliberation forum. Public collaboration with the government signifies that democracy is visible, and dynamic. The values contained in Anies Baswedan are expressed in the form of communication in the debate discourse.

\section{Conclusion}

The sentence forms contained in the language used by Anis Baswedan are in the form of active sentences. The use of Anis Baswedan's active sentence in the debate is a strategy of selfprominence as a subject who occupies a central position as a candidate for the Governor of DKI Jakarta. The pronouns in the language used by Anis Baswedan in the DKI Jakarta Pilkada debate include: us, me, and us. Overall, the use of our pronouns is the highest number among other pronouns used by Anis in the debate. This indicates that Anis Baswedan is a prospective leader who has the character of collaborative leadership and high commitment. The lexicon in the language used by Anis Baswedan in the DKI Jakarta election debate reflects the ideology of the Pancasila. Anis Baswedan also uses the metaphor feature in the debate. The metaphor is a figure of figure and a meaningful expression. The leadership value contained in the language used by Anies Baswedan in the DKI Jakarta Pilkada debate is democratic leadership. The value of democratic leadership is quantitatively composed of aspects of democratic leadership which are the most dominant as follows: (1) social justice; (2) national ideals; (3) a balance between rights and obligations; (4) responsible freedom; (5) equation; (6) family and national unity; and (7) deliberation.

\section{References}

[1] I. Schoon, E. Jones, H. Cheng, and B. Maughan, "Family hardship, family instability, and cognitive development," J. Epidemiol. Community Health, vol.66, no.8, pp.716-722, (2012) DOI: 10.1136/jech.2010.121228.

[2] T. A. van Dijk, "Ideology and discourse analysis," J. Polit. Ideol., vol.11, no.2, pp.115-140, (2006) DOI: 10.1080/13569310600687908.

[3] A. Puckett, "Language and power," in Talking Appalachian: Voice, Identity, and Community, (2013)

[4] I. Hussein, "Critical Discourse Analysis of the Political Speech of the Egyptian President, Abdel Fattah El-Sisi, at the New Suez Canal Inauguration Ceremony," Int. J. Lang., vol.4, no.1, pp.85-106, (2016) DOI: 10.15640/ij1l.v4n1a10.

[5] S. Esmaeili and A. Arabmofrad, "A critical discourse analysis of family and friends textbooks: Representation of genderism," Int. J. Appl. Linguist. English Lit., vol.4, no.4, pp.55-61, (2015) DOI: 10.7575/aiac.ijalel.v.4n.4p.55.

[6] M. S. Al Fajri, "Hegemonic and minority discourses around immigrants: A corpus-based critical discourse analysis,” Indones. J. Appl. Linguist., vol.7, no.2, pp.381-390, (2017) DOI: 10.17509/ijal.v7i2.8349.

[7] N. Fairclough, Critical discourse analysis the critical study of language, second edition. Routledge. (2013)

[8] J. Wang, “A Critical Discourse Analysis of Barack Obama’s Speeches,” J. Lang. Teach. Res., vol.1, no.3, pp.254-261, (2010) DOI: 10.4304/jltr.1.3.254-261.

[9] S. Davis, W. Buskist, and R. L. Miller, "Leadership: Theory and Practice," in 21st Century Psychology: A Reference Handbook, (2012)

[10] Ideology: A Multidisciplinary Approach. (2012) 
[11] T. A. van Dijk, "Critical Discourse Studies: A Sociocognitive Approach," in Methods of Critical Discourse Analysis, vol.2, no.1, pp.62-86, (2009)

[12] T. A. van Dijk, “Aims of Critical Discourse Analysis," Japanese Discourse, (1995)

[13] B. Kazemian and S. Hashemi, "Critical discourse analysis of Barack Obama's 2012 speeches: Views from systemic functional linguistics and Rhetoric,” Theory Pract. Lang. Stud., vol.4, no.6, pp.1178-1187, (2014) DOI: $10.4304 /$ tpls.4.6.1178-1187.

[14] M. A. Baum and T. Groeling, "New media and the polarization of American political discourse," Polit. Commun., vol.25, no.4, pp.345-365, (2008) DOI: 10.1080/10584600802426965.

[15] N. F. M. Nor and J. Aziz, "Discourse analysis of decision making episodes in meetings: Politeness theory and critical discourse analysis,” 3L Lang. Linguist. Lit., vol.16, no.2, (2010)

[16] E. Sarfo and E. A. Krampa, "Language at war: A critical discourse analysis of speeches of Bush and Obama on terrorism,” Int. J. Soc. Sci. Educ., vol.3, no.2, (2013)

[17] P. L. Yang, “A critical discourse analysis of Taiwan's national debate on economic TIES with China," Taiwan J. Linguist., vol.11, no.2, pp.83-103, (2013) DOI: 10.6519/TJL.2013.11(2).4.

[18] R. E. Goodin, P. Pettit, and T. Pogge, A companion to contemporary political philosophy. 2008.

[19] A. Y. Zhou, “\#Republic: Divided Democracy in the Age of Social Media," Princeton University Press, (2017) DOI: $10.1111 /$ jcom.12344.

[20] D. V. Day, J. W. Fleenor, L. E. Atwater, R. E. Sturm, and R. A. McKee, "Advances in leader and leadership development: A review of 25 years of research and theory," Leadership Quarterly. vol.25, no.1, pp.63-82, (2014) DOI: 10.1016/j.leaqua.2013.11.004.

[21] J. McCleskey, "Situational, transformational, and transactional leadership and leadership development," J. Bus. Stud. Q., vol.5, no.4, p. 117, (2014) 